\title{
Gas Gangrene of the Liver after a Choledocho-Jejunostomy
}

\section{M.G. Buimer E.J. Spillenaar Bilgen}

Department of Surgery, Rijnstate Hospital, Arnhem, The Netherlands

A 57-year-old female was referred to our surgical department because of a carcinoma in the head of the pancreas. We performed a laparotomy and found a metastasis next to the hepatic artery and therefore a choledochojejunostomy and a gastro-enterostomy were created. The patient recovered rapidly. Unexpectedly, the day before the planned discharge, she developed abdominal pain in the right upper quadrant with fever up to $39^{\circ} \mathrm{C}$. Laboratory studies showed a white cell count of $47,700 / \mathrm{mm}^{3}$ and

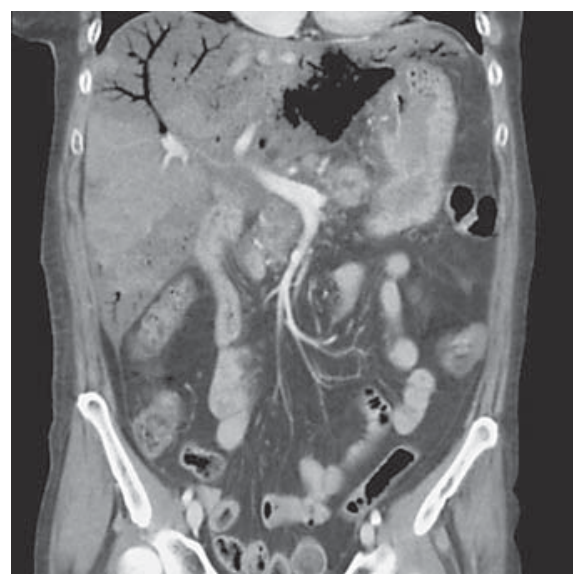

Fig. 1. CT scan showing necrosis of the liver with air in the bile ducts.

\section{KARGER}

Fax +41613061234 E-Mail karger@karger.ch www.karger.com

\section{(C) 2008 S. Karger AG, Basel}

0253-4886/08/0254-0260\$24.50/0

Accessible online at:

www.karger.com/dsu
C-reactive protein of $253 \mathrm{mg} / \mathrm{l}$. Liver tests showed an alkaline phosphatase of $270 \mathrm{IU} / \mathrm{l}$, alanine aminotransferase of $707 \mathrm{IU} / 1$, aspartate aminotransferase of 1,912 IU/1, total bilirubin of $59 \mu \mathrm{mol} / \mathrm{l}$, lactate dehydrogenase of 4,678 IU/l and $\gamma$-glutamyl-transpeptidase of $94 \mathrm{IU} / \mathrm{l}$.

A CT scan revealed partial necrosis of the liver, especially the left liver lobe, with extensive air in the bile ducts and the parenchyma concordant to gas gangrene (fig. 1, 2). Several hours later the patient died. At autopsy, the

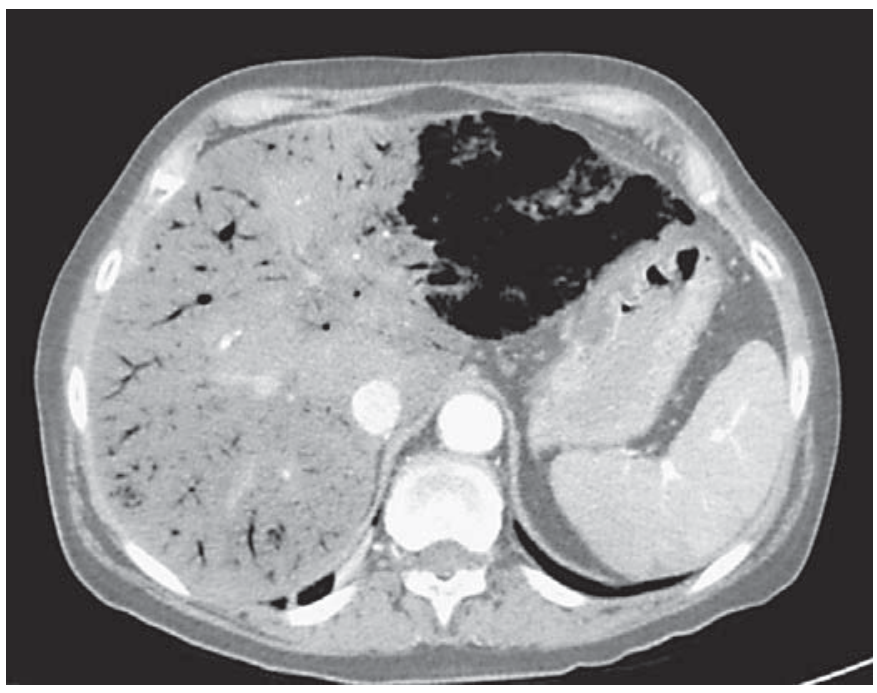

Fig. 2. CT scan with necrosis of the left liver lobe and partial necrosis of the right liver lobe with air in the bile ducts. 
pathologist found diffuse gas gangrene of the liver with total necrosis of the left liver lobe. There were no signs of leakage at the choledocho-jejunostomy and gastro-enterostomy.

Microscopy showed extensive necrosis with cavities in the liver parenchyma surrounded by Gram-positive bacteria. Cultures of liver parenchyma revealed Clostridium perfringens.

Since the first description of gas gangrene of an organ by Fraenkel in 1889, few cases of acute organ failure following acute $C$. perfringens infection have been described in the literature [1-4].
References

$>1$ Bergert H, Illert T, Friedrich K, Ockert D: Fulminant liver failure following infection by Clostridium perfringens. Surg Infect (Larchmt) 2004;5:205-209.

$\checkmark 2$ Kuroda S, Okada Y, Mita M, Okamoto Y, Kato H, Ueyama S, Fujii L, Morita S, Yoshida Y: Fulminant massive gas gangrene caused by Clostridium perfringens. Intern Med 2005; 44:499-502.

$\checkmark 3$ Weinstein L, Barza MA: Gas gangrene. N Engl J Med 1973;289:1129-1131.

$\checkmark 4$ Stevens DL: The pathogenesis of clostridial myonecrosis. Int J Med Microbiol 2000;290: 497-502. 